\title{
Measurement of physical activity and sedentary behavior in national health surveys, South America
}

\author{
Danilo R. Silva', Luciana L. Barboza², Se-Sergio Baldew³ ${ }^{3}$ Cecilia Anza-Ramirez ${ }^{4}$, Robinson \\ Ramírez-Vélez ${ }^{5}$, Felipe B. Schuch ${ }^{6}$, Thayse N. Gomes ${ }^{1}$, Kabir P. Sadarangani ${ }^{7}$, Antonio García-Hermoso ${ }^{5}$, \\ Ramfis Nieto-Martinez ${ }^{8}$, Gerson Ferrari ${ }^{9}$, J. Jaime Miranda ${ }^{4}$, André O. Werneck ${ }^{10}$, on behalf of the \\ South American Physical Activity and Sedentary Behavior Network (SAPASEN) collaborators
}

Suggested citation Silva DR, Barboza LL, Baldew S, Anza-Ramirez C, Ramírez-Vélez R, Schuch FB, et al. Measurement of physical activity and sedentary behavior in national health surveys, South America. Rev Panam Salud Publica. 2022;46:e7. https://doi.org/10.26633/RPSP.2022.7

ABSTRACT

Objectives. To characterize how physical activity and sedentary behavior have been measured in national health surveys in South American countries.

Methods. An extensive search was made for national health surveys from all 12 South American countries through health websites, national statistical offices, and contact with researchers and policy-makers. The following eligibility criteria were used to select surveys: conducted in a South American country; used a nationally representative sample $\geq 18$ years; coordinated by the public, private or mixed private-public sector; and assessed physical activity and/or sedentary behavior. Data were extracted on general information about the surveys, specific details about the physical activity and sedentary behavior assessment, and additional questions related to activity behavior.

Results. In total, 36 surveys were included, two of which were multicountry surveys; all surveys assessed physical activity and 27 assessed sedentary behavior. Most surveys (23/36; 64\%) were based on previously validated international questionnaires, but 13 (57\%) of these deviated from the reference tools, introducing changes and adaptations. Sedentary behavior was assessed mostly through questions on screen time and/ or daily sitting time in the same physical activity questionnaires. No survey used device-based measures to generate data on these behaviors.

Conclusions. Differences between instruments used and modifications limit the comparability of data across countries. This highlights the importance of standardizing assessment within South America for physical activity and sedentary behavior sections in national surveys, with the broader aim of contributing to establishing a standardized strategy for the surveillance of physical activity and sedentary behavior in South America.

Keywords $\quad$ Exercise; sedentary behavior; health surveys; population surveillance; South America.

Physical inactivity and sedentary behavior are associated with negative health outcomes and elevated costs in health systems, representing a challenge in public health for countries

\footnotetext{
Federal University of Sergipe - UFS, São Cristóvão, Brazil $₫$ Danilo R. Silva, danilorpsilva@gmail.com

2 University of Brasilia, Brasília, Brazil

3 Anton de Kom University of Suriname, Paramaribo, Suriname

4 Universidad Peruana Cayetano Heredia, Lima, Peru

Public University of Navarra, Pamplona, Navarra, Spain
}

of all income levels (1-4). Despite the benefits of both increasing physical activity and reducing sedentary behavior, Latin America and the Caribbean have the highest levels of physical 
inactivity worldwide (5). About $40 \%$ of adults in South America do not achieve 150 minutes a week of physical activity, and nearly half of all adults spend more than 4 hours a day sitting (6). Given these alarmingly high rates, several South American countries have created specific national health agendas targeting physical activity, but they have not necessarily placed equal emphasis on reducing sedentary behavior (7).

Alongside the development and implementation of effective strategies to stimulate physical activity and reduce sedentary behavior, it is essential to have well established nationwide surveillance of these two behaviors. Monitoring activities could help countries identify the prevalence, distribution, potential determinants and trends over time of physical activity and sedentary behavior, and the effectiveness of public health interventions to address them (8-11).

Regional surveillance of physical activity has already been initiated and implemented, and could serve as example for other regions (12). For instance, the European Union developed and implemented the European Health Interview Survey Physical Activity Questionnaire (EHIS-PAQ) to be used by all European Union member states, which will make it possible to make regional comparisons and evaluations of health targets (13). A similar endeavor would also benefit South America (14). To date, no analysis has explored the similarities and differences between the various South American surveys that have been used for the assessment of physical activity and sedentary behavior. Therefore, the present study aimed to characterize how physical activity and sedentary behavior have been measured in national health surveys in South American countries.

\section{METHODS}

The selection of the national surveys was conducted in three phases. First, we searched for surveys on the websites of health and national statistical offices of each South American country. Second, the identified surveys were presented to the members of the South American Physical Activity and Sedentary Behavior Network (14) in order to verify them. In addition, in this phase, representatives of the health sectors of South American countries were contacted asking for any additional surveys. All the websites consulted and contacts of the health sectors of the countries are available from the authors on request.

From all the surveys provided, we selected those that met the following eligibility criteria: (i) conducted in a South American country, with no date restrictions; (ii) used a nationally representative sample of adults ( $\geq 18$ years); (iii) coordinated by the public, private or mixed private-public sector, including academic research groups; and (iv) included assessment of physical activity and/or sedentary behavior. Surveys that also included people younger than 18 years in their age range were eligible.

In the third phase, two of the authors summarized all extraction forms in tables that were checked by the co-authors. Data extracted included: general information about the surveys (country, year, name of the survey, data collection strategy and sample age range); specific details about the physical activity and sedentary behavior assessment (questionnaires/questions used, time reference and domains / context assessed); and additional questions related to the activity behaviors (e.g. reasons for and perceptions of physical activity and sports practice). We conducted a narrative review to synthesize information of each survey.

\section{RESULTS}

We identified 34 surveys across all 12 South American countries and two multicountry surveys with data from more than one country. General information on each national health survey that assessed physical activity is presented in Table 1. Surveys were conducted between 2003 (Chile) and 2020 (Venezuela), and the number of surveys conducted over this period in each country ranged from one (Guyana, Paraguay, and Suriname) to six (Peru). Among the countries with more than one survey, Argentina, Bolivia, Chile, and Venezuela had conducted only one type of survey, whereas Brazil, Colombia, Ecuador, Peru, and Uruguay had more than one type of survey. In addition, two multicenter surveys were conducted at one time point each. Data were collected by personal interview in 35 surveys (six reported the use of an electronic collector or personal digital assistants, four in Brazil, and one each in Chile and Paraguay); it was not clear how data were collected in one survey (Uruguay).

Of the questionnaires used, nine surveys used the Global Physical Activity Questionnaire (GPAQ) (15), six used the short version of the International Physical Activity Questionnaire (IPAQ), and six used the long version of the IPAQ (16). Three surveys used only specific domains of the IPAQ long version and one survey used another questionnaire including all four physical activity domains. Thirteen surveys from six countries (Argentina, Colombia, Ecuador, Guyana, Peru, and Suriname) and a multicountry survey used questionnaires that deviated from the reference ones (description, examples, or sections). Surveys generally followed the reference time of the questionnaires (GPAQ: typical week; IPAQ: last 7 days). Among the multicenter surveys, the Latin American Study of Nutrition and Health used the transport and leisure domains of the IPAQ long version and included a device-based measure through accelerometers, in part of their samples (about 30\%). The World Health Survey used the IPAQ short version.

We found that some surveys adapted questions from the reference physical activity instruments. Argentina's survey (which used the IPAQ short version) included binary questions about the domains in its 2013 version. The surveys in Brazil (Pesquisa Nacional por Amostra de Domicílios 2015), Colombia (Encuesta Nacional de Salud 2007), and Chile (Encuesta Nacional de Salud 2003) used independent questions for leisure physical activity only. Bolivia used questions on achieving 30 minutes a day of physical activity regardless of the domain. Brazil (Pesquisa Nacional por Amostra de Domicílios 2008), Paraguay, and Peru (Encuesta Demográfica y de Salud Familiar 2011, 2012 and 2013) adopted independent questions for specific domains of physical activity. The Encuesta Nacional de Salud in Uruguay adopted a general question considering all domains.

Of the 36 surveys, 27 also assessed for sedentary behavior (Table 2). The assessment of sedentary behavior was generally included in the physical activity questionnaires. The short version of the GPAQ and IPAQ consider a single question about the total time (hours and minutes) spent sitting on a typical day or during the last 7 days, respectively. The long version of the IPAQ is similar to the short version but separates responses into week and weekend days. The Encuesta Nacional de Demografía y Salud, (Bolivia), the Pesquisa Nacional por Amostra de Domicílios 2008 (Brazil), the Pesquisa Nacional de Saúde 2019 (Brazil), the Encuesta Nacional de Salud (Uruguay), 


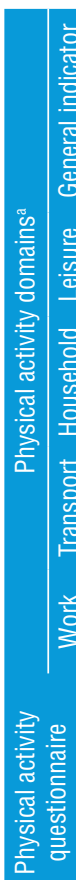

$\times \times \times \times \times \times$

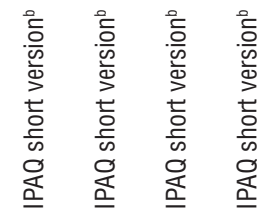

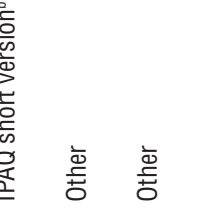

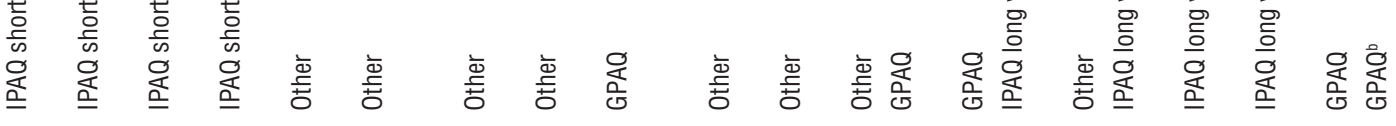

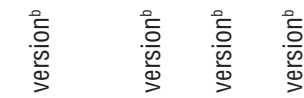



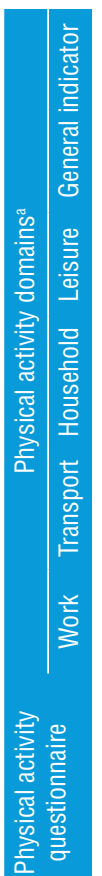

흘

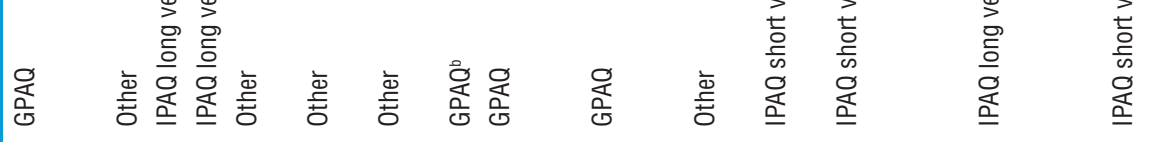

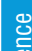

离

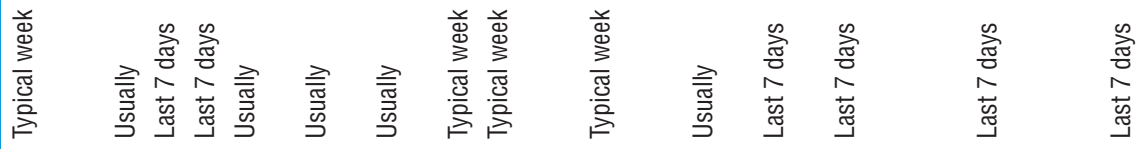

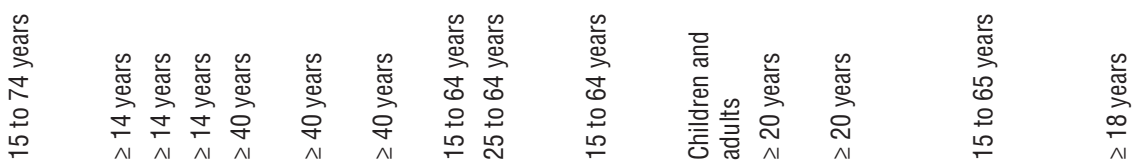

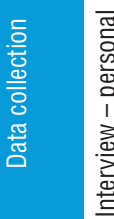

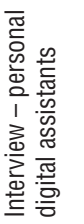

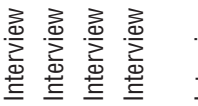

产

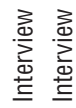

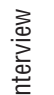

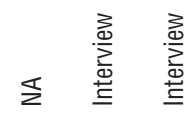

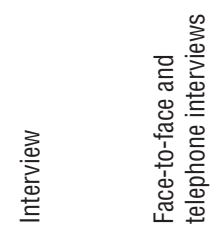

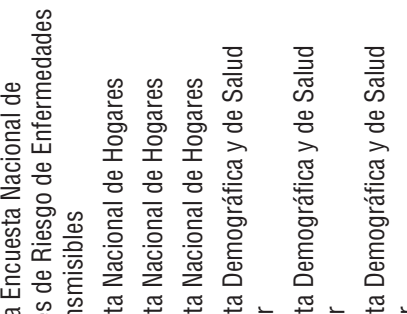

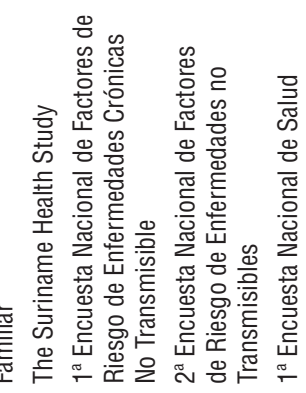

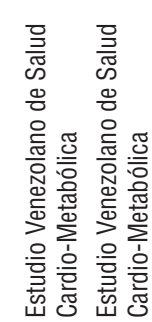

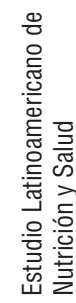

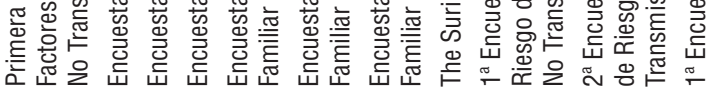

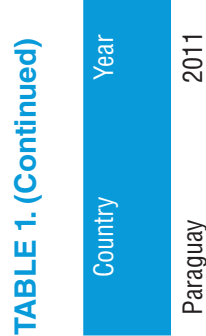

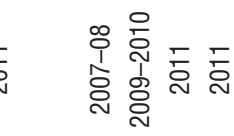

กั่

商 茓

芒

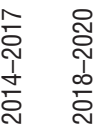

(1)

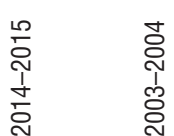

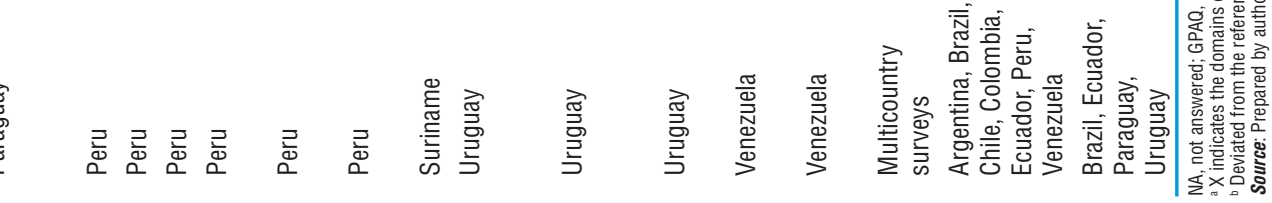


TABLE 2. Information on sedentary behavior from national health surveys in South American countries

\begin{tabular}{|c|c|c|}
\hline Country & Year & Survey \\
\hline Argentina & 2005 & $1^{a}$ Encuesta Nacional de Factores de Riesgo \\
\hline Argentina & 2009 & $2^{a}$ Encuesta Nacional de Factores de Riesgo \\
\hline Argentina & 2013 & $3^{\mathrm{a}}$ Encuesta Nacional de Factores de Riesgo \\
\hline Argentina & 2018 & $4^{a}$ Encuesta Nacional de Factores de Riesgo \\
\hline Bolivia & 2008 & $\begin{array}{l}\text { Encuesta Nacional de Demografía y Salud } \\
\text { ENDSA }\end{array}$ \\
\hline
\end{tabular}

\begin{tabular}{|c|c|c|}
\hline Bolivia & 2016 & Encuesta de demografía y salud ENDSA \\
\hline Brazil & 2008 & $\begin{array}{l}\text { Pesquisa Nacional por Amostra } \\
\text { de Domicílios }\end{array}$ \\
\hline Brazil & 2013 & Pesquisa Nacional de Saúde \\
\hline Brazil & 2013 & $\begin{array}{l}\text { Pesquisa Nacional sobre o Acesso, } \\
\text { Utilização, e Promoção do Uso Racional de } \\
\text { Medicamentos no Brasil }\end{array}$ \\
\hline Brazil & 2019 & Pesquisa Nacional de Saúde \\
\hline
\end{tabular}

\begin{tabular}{|c|c|c|}
\hline Chile & 2016-2017 & Encuesta Nacional de Salud \\
\hline Colombia & 2015 & $\begin{array}{l}\text { Encuesta Nacional de la Situación } \\
\text { Nutricional en Colombia }\end{array}$ \\
\hline Ecuador & 2018 & Ecuador Encuesta STEPS 2018 \\
\hline Guyana & 2016 & STEPS survey \\
\hline Paraguay & 2011 & $\begin{array}{l}\text { Primera Encuesta Nacional de Factores de } \\
\text { Riesgo de Enfermedades No Transmisibles }\end{array}$ \\
\hline
\end{tabular}

$\begin{array}{lll}\text { Peru } & 2009-2010 & \text { Encuesta Nacional de Hogares } \\ \text { Peru } & 2011 & \text { Encuesta Nacional de Hogares }\end{array}$

$2011 \quad$ Encuesta Demográfica y de Salud Familiar

$2012 \quad$ Encuesta Demográfica y de Salud Familiar

$2013 \quad$ Eeru $\quad$ Encuesta Demográfica y de Salud Familiar

\begin{tabular}{|c|c|c|}
\hline Suriname & 2013 & The Suriname Health Study \\
\hline Uruguay & 2006 & $\begin{array}{l}1^{\text {a }} \text { Encuesta Nacional de Factores de } \\
\text { Riesgo de Enfermedades Crónicas No } \\
\text { Transmisible }\end{array}$ \\
\hline Uruguay & 2013 & $\begin{array}{l}2^{\mathrm{a}} \text { Encuesta Nacional de Factores de } \\
\text { Riesgo de Enfermedades no Transmisibles }\end{array}$ \\
\hline Uruguay & 2014 & 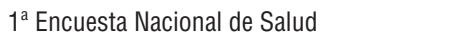 \\
\hline Venezuela & $2015-2017$ & $\begin{array}{l}\text { Estudio Venezolano de Salud } \\
\text { Cardio-Metabólica }\end{array}$ \\
\hline Venezuela & 2020 & $\begin{array}{l}\text { Estudio Venezolano de Salud } \\
\text { Cardio-Metabólica }\end{array}$ \\
\hline
\end{tabular}

Multicountry

surveys

Argentina, 2014-2015 Estudio Latinoamericano de Nutrición

Brazil, Chile,

Colombia,

Ecuador, Peru,

Venezuela

TV, television; $\mathrm{CD}$, compact disc.
a This question was used as proxy of sedentary behavior and asked about the following activties: (i) computer use at home; (ii) video game use; (iii) reading (books/magazines); (iv) socializing with friends or family or listening to music/ CDs/radio; (v) talking on the telephone; (vi) watching TV at home; and (vii) time spent inside a motor vehicle (car, motorcycle, train or bus).

Source: Prepared by authors based on official surveys reports. 
and the Latin American Study of Nutrition and Health were the only surveys that considered more than one type of sitting time (e.g. television-viewing, computer or video games, reading a newspaper, and listening to the radio). Some minor wording and structure changes were noted in questions on sedentary behavior (e.g. sedentary activity instead of sitting time - Primera Encuesta Nacional de Factores de Riesgo de Enfermedades No Transmisibles in Paraguay).

Additional questions about physical activity were included in 14 national surveys (available from authors on request). The reasons for doing or not doing physical activity were asked in surveys in Argentina and Uruguay, and in the two Brazilian surveys. Bolivian surveys asked about the perception of the benefits of physical activity and the Brazilian surveys included information about sports practice (past and present), as well as the environment, public policies and programs for physical activity. The first survey in Chile (2003) included a general question about the perception of the respondent's own behavior during the day, and the last survey in Chile (2016-2017) had complementary questions on characteristics of specific domains and activities (transport). The Guyana survey used questions on access to information about physical activity. The Latin American Study of Nutrition and Health adopted specific information on environmental correlates of movement behaviors.

\section{DISCUSSION}

Information on physical activity does exist and is available from representative samples across all 12 South American countries. Although most of the surveys used the GPAQ or IPAQ $(23 / 36,64 \%)$, about half of them (13/23, 57\%) did not use the reference version of the questionnaires and used only domain-specific questions or changed reference questions. The use of GPAQ and IPAQ was why information about sedentary behavior was available for all countries. With few exceptions, the surveys did not investigate the full spectrum of sedentary activities, such as lying down or reclining, but used instead single questions about sitting time of the physical activity questionnaires (17). This may be because evidence on the role of sedentary behaviors as a risk factor for physical and mental diseases is more recent compared with the evidence on physical inactivity (18).

On a global level, a nationwide surveillance of physical activity and sedentary behavior allows for international comparisons and adequate monitoring of whether targets for these behaviors are attained or not (19). However, surveillance efforts vary across countries and depend on country priorities. While some high-income countries are already using wearable devices to objectively measure physical activity and sedentary time in their populations $(20,21)$, most low- and middle-income countries still rely on self-reporting methods as the main way to collect such data in their national health surveys.

Although South American countries have included questionnaires and/or questions about physical activity in their national surveys, the way this information has been generated deserves careful attention. Both the GPAQ and the IPAQ (short and long versions), although widely used and accepted, tend to show mixed psychometric properties depending on the region in the world and population subgroup (15, 22-25). In addition, using adapted versions, selecting some questions from each questionnaire and rephrasing them, adapting the question, or not including all domains of the questionnaires (i.e. leisure, work, household, and transport) could affect the psychometric properties of the instruments and thus affect their validity and reliability. Furthermore, the changes introduced through adaptations made to the reference tools and the addition of questions, as evidenced by our results, could potentially undermine comparisons between countries (26-32). Given these characteristics, further investigation on the psychometric properties of the adapted instruments should be conducted in the South American context in order to assess the quality of the measures generated.

Some countries also assessed complementary information about physical activity, such as reasons for practising specific types of sports (or not) and past practices. This assessment does not seem to follow any standard and appears to be more related to the interests and expectations of each surveillance system and policy-makers.

Since one of the main aims of monitoring physical activity and sedentary behavior is to assess the prevalence of these behaviors at the population level (active versus inactive; sedentary versus non-sedentary), instruments are not always able to capture all aspects of physical activity and sedentary behavior. Similar to most countries (33), muscle strengthening and balance exercises are not specifically assessed in the South American surveys, although this has been recommended in public health guidelines on physical activity (34). Until recently, research on sedentary behavior has relied on self-report measures and has primarily been examined through screen-based behaviors, which explains the questions used by the surveys. Although consensus is lacking on cut-offs for sedentary behavior, interest in its specific manifestations (e.g. TV-viewing, smartphone use, and reading) and their patterns (e.g. timing, duration of bouts, and frequency of breaks) are growing $(18,35)$. Previous work suggests that despite the importance of screen time, it alone may not be a good marker for sedentary behavior, which highlights the need to assess a variety of sedentary behaviors (36).

Surveys can also be used to identify trends over time. Most of the countries, except for Guyana and Suriname, conducted at least two surveys in different years allowing time trend analysis of physical activity and sedentary behavior in nine and five countries, respectively. However, in some countries, differences between the questionnaires used in the different surveys did not allow valid analysis of time trends. However, in Argentina, Brazil, Bolivia, Chile, Colombia, Peru, Uruguay, and Venezuela the same surveys were used at different times, thus allowing time comparisons within the countries, but not necessarily across countries since they used different tools.

As recommendations derived from international physical activity guidelines may change over time, attention should also be given to preserving the time comparability (evaluation of public health practice) (37) or adjusting questionnaires (data generation) to new guidelines. For example, the interest in the integrative view of behaviors during the 24 hours of the day, the incorporation of different physical activity intensities, sedentary behaviors and sleep (38-40), as well as the removal of the criterion that physical activity should be performed in bouts of at least 10 minutes in the most recent guidelines on physical activity and sedentary behavior of the World Health Organization (41) can demand adjustments on the surveillance systems.

In view of the multiple dimensions of physical activity and sedentary behaviors (e.g. frequency, intensity, pattern, context, 
type, and reasons for a particular behavior), public health systems are faced with hard decisions on their priorities and the costs associated with surveys to be conducted at the population level. In addition, although indicators of sedentary behavior are slightly more consistent, the comparability of physical activity indicators from national health surveys from South American countries can be affected by the different measures used. For example, the IPAQ questionnaire overestimates physical activity compared with the GPAQ and it is possible to create a correction (5) based on the differences between IPAQ and GPAQ. However, the use of other less known questionnaires which contain only part of domains or even domain-specific questions are a major challenge for harmonization of the physical activity data. To increase between-country comparability, countries should discuss the adoption of standardized measures within their national health surveys, or at least consistently use the reference questionnaires.

This comprehensive narrative review has limitations. We focused on the assessment of movement behaviors and individual methodological characteristics of the national surveys were not considered, e.g. sampling design, age ranges of participants, training of personnel, or response rates. Since this review considered only nationally representative surveys, it is possible that further surveys exist that are less comprehensive but which could provide additional evidence of physical activity and sedentary behavior for specific municipalities or regions in South America; for example the VIGITEL which represents states capitals in Brazil and provides different indicators of movement behaviors (42). However, this is the first review of physical activity and sedentary behavior surveillance among adults from South American countries and it aimed to improve our understanding of the assessment of physical activity and sedentary behavior in the continent (43). Our review points to the importance of standardizing assessment within South America when considering future national surveys and/or future implementation/modification of the physical activity and sedentary behavior sections in national surveys, with the broader aim of contributing towards establishing a standardized strategy for the surveillance of physical activity and sedentary behavior in the South American region.

In conclusion, information about physical activity and sedentary behavior derived from national surveys from all South American countries is available. Although assessment instruments vary among surveys, the most used were GPAQ, IPAQ or questions/specific domains of these questionnaires. Sedentary behavior has not been assessed as an independent behavior, but through single questions in physical activity questionnaires. These findings will help inform the strengths and weaknesses of comparison efforts of existing data on physical activity and sedentary behaviors in the region. Similarly, this study points to essential minimum requirements for future standardization efforts to generate meaningful comparable data across countries to enable broader monitoring and evaluation of physical activity and sedentary behaviors, which have such important public health relevance.

Author contributions. DRS, LLB and AOW conceived the original idea, designed the work, and wrote the first draft of the work. All authors interpreted the data, revised the work critically with important intellectual content, and approved the final version of the work.

\section{Conflicts of interests. None declared.}

Funding. This research received no specific grant from any funding agency in the public, commercial, or not-for-profit sectors. The views expressed in this publication are those of the authors and not necessarily those of the acknowledged institutions.

Disclaimer. The authors are solely responsible for the views expressed in the manuscript, which may not necessarily reflect the opinion or policy of the Revista Panamericana de Salud Pública / Pan American Journal of Public Health and/or those of the Pan American Health Organization, nor those of the institutions to which the authors are affiliated.

\section{REFERENCES}

1. Hafner M, Yerushalmi E, Stepanek M, Phillips W, Pollard J, Deshpande A, et al. Estimating the global economic benefits of physically active populations over 30 years (2020-2050). Br J Sports Med. 2020;54(24):1482-87.

2. Lee IM, Shiroma EJ, Lobelo F, Puska P, Blair SN, Katzmarzyk PT, et al. Effect of physical inactivity on major non-communicable diseases worldwide: an analysis of burden of disease and life expectancy. Lancet. 2012;380(9838):219-29.

3. Ding D, Lawson KD, Kolbe-Alexander TL, Finkelstein EA, Katzmarzyk PT, van Mechelen W, et al. The economic burden of physical inactivity: a global analysis of major non-communicable diseases. Lancet. 2016;388(10051):1311-24.

4. Heron L, O'Neill C, McAneney H, Kee F, Tully MA. Direct healthcare costs of sedentary behaviour in the UK. J Epidemiol Community Health. 2019;73(7):625-29.

5. Guthold R, Stevens GA, Riley LM, Bull FC. Worldwide trends in insufficient physical activity from 2001 to 2016: a pooled analysis of
358 population-based surveys with 1.9 million participants. Lancet Glob Health. 2018;6(10):e1077-e86.

6. Werneck AO, Baldew SS, Miranda JJ, Díaz Arnesto O, Stubbs B, Silva DR. Physical activity and sedentary behavior patterns and sociodemographic correlates in 116982 adults from six South American countries: the South American physical activity and sedentary behavior network (SAPASEN). Int J Behav Nutr Phys Act. 2019;16(1):68.

7. Varela AR, Pratt M, Powell K, Lee IM, Bauman A, Heath G, et al. Worldwide surveillance, policy, and research on physical activity and health: the Global Observatory for Physical Activity. J Phys Act Health. 2017;14(9):701-9.

8. Tolonen H, Koponen P, Al-Kerwi A, Capkova N, Giampaoli S, Mindell J, et al. European health examination surveys - a tool for collecting objective information about the health of the population. Arch Public Health. 2018;76:38.

9. Kilpeläinen $\mathrm{K}$, Koponen $\mathrm{P}$, Tolonen $\mathrm{H}$, Koskinen S, Borodulin $\mathrm{K}$, Gissler M. From monitoring to action: utilising health survey data in 
national policy development and implementation in Finland. Arch Public Health. 2019;77(1):48.

10. Pate R, Berrigan D, Buchner D, Carlson S, Dunton G, Fulton J, et al. Actions to improve physical activity surveillance in the United States. NAM Perspectives. 2018;8.

11. Kohl HW, 3rd, Craig CL, Lambert EV, Inoue S, Alkandari JR, Leetongin $\mathrm{G}$, et al. The pandemic of physical inactivity: global action for public health. Lancet. 2012;380(9838):294-305.

12. Guthold R, Louazani SA, Riley LM, Cowan MJ, Bovet P, Damasceno A, et al. Physical activity in 22 African countries: results from the World Health Organization STEPwise approach to chronic disease risk factor surveillance. Am J Prev Med. 2011;41(1):52-60.

13. Finger JD, Tafforeau J, Gisle L, Oja L, Ziese T, Thelen J, et al. Development of the European Health Interview Survey - Physical Activity Questionnaire (EHIS-PAQ) to monitor physical activity in the European Union. Arch Public Health. 2015;73:59.

14. Werneck AO, Baldew SS, Miranda JJ, Incarbone O, Silva DR. The South American Physical Activity and Sedentary Behavior Network (SAPASEN). Glob Health Promot. 2020;27(3):171-6.Bull FC, Maslin TS, Armstrong T. Global physical activity questionnaire (GPAQ): nine country reliability and validity study. J Phys Act Health. 2009;6(6):790-804.

15. Bull FC, Maslin TS, Armstrong T. Global physical activity questionnaire (GPAQ): nine country reliability and validity study. J Phys Act Health. 2009;6(6):790-804.

16. Craig CL, Marshall AL, Sjöström M, Bauman AE, Booth ML, Ainsworth BE, et al. International physical activity questionnaire: 12-country reliability and validity. Med Sci Sports Exerc. 2003:35(8):1381-95.

17. McLaughlin M, Atkin AJ, Starr L, Hall A, Wolfenden L, Sutherland $\mathrm{R}$, et al. Worldwide surveillance of self-reported sitting time: a scoping review. Int J Behav Nutr Phys Act. 2020;17(1):111.

18. Tremblay MS, Aubert S, Barnes JD, Saunders TJ, Carson V, LatimerCheung AE, et al. Sedentary Behavior Research Network (SBRN) terminology consensus project process and outcome. Int J Behav Nutr Phys Act. 2017;14(1):75.

19. Strain T, Wijndaele K, Garcia L, Cowan M, Guthold R, Brage S, et al. Levels of domain-specific physical activity at work, in the household, for travel and for leisure among 327789 adults from 104 countries. Br J Sports Med. 2020;54(24):1488-97.

20. Strain T, Wijndaele K, Brage S. Physical activity surveillance through smartphone apps and wearable trackers: examining the UK potential for nationally representative sampling. JMIR Mhealth Uhealth. 2019;7(1):e11898.

21. LaMunion SR, Fitzhugh EC, Crouter SE. Challenges and opportunities related to the objective assessment of physical activity within U.S. health surveys. Ann Epidemiol. 2020;43:1-10.

22. Lee PH, Macfarlane DJ, Lam TH, Stewart SM. Validity of the international physical activity questionnaire short form (IPAQ-SF): a systematic review. Int J Behav Nutr Phys Act. 2011;8(1):115.

23. Sember V, Meh K, Sorić M, Starc G, Rocha P, Jurak G. Validity and reliability of international physical activity questionnaires for adults across EU countries: systematic review and meta analysis. Int J Environ Res Public Health. 2020;17(19):7161.

24. Cleland CL, Hunter RF, Kee F, Cupples ME, Sallis JF, Tully MA. Validity of the global physical activity questionnaire (GPAQ) in assessing levels and change in moderate-vigorous physical activity and sedentary behaviour. BMC Public Health. 2014;14:1255.

25. Hallal PC, Gomez LF, Parra DC, Lobelo F, Mosquera J, Florindo AA, et al. Lessons learned after 10 years of IPAQ use in Brazil and Colombia. J Phys Act Health. 2010;7(Suppl 2):S259-64.

26. Mindell JS, Moody A, Vecino-Ortiz AI, Alfaro T, Frenz P, Scholes S, et al. Comparison of health examination survey methods in Brazil, Chile, Colombia, Mexico, England, Scotland, and the United States. Am J Epidemiol. 2017;186(6):648-58.

27. Strain T, Milton K, Dall P, Standage M, Mutrie N. How are we measuring physical activity and sedentary behaviour in the four home nations of the UK? A narrative review of current surveillance measures and future directions. Br J Sports Med. 2020;54(21):1269-76.
28. Prince SA, Melvin A, Roberts KC, Butler GP, Thompson W. Sedentary behaviour surveillance in Canada: trends, challenges and lessons learned. Int J B Behav Nutr Phys Act. 2020;17(1):34.

29. Williamson C, Kelly P, Strain T. Different analysis methods of Scottish and English child physical activity data explain the majority of the difference between the national prevalence estimates. BMC Public Health. 2019;19(1):171.

30. Warren JM, Ekelund U, Besson H, Mezzani A, Geladas N, Vanhees L. Assessment of physical activity - a review of methodologies with reference to epidemiological research: a report of the exercise physiology section of the European Association of Cardiovascular Prevention and Rehabilitation. Eur J Cardiovasc Prev Rehabil. 2010;17(2):127-39.

31. Canning KL, Brown RE, Jamnik VK, Salmon A, Ardern CI, Kuk JL. Individuals underestimate moderate and vigorous intensity physical activity. PLoS One. 2014;9(5):e97927.

32. Strath SJ, Kaminsky LA, Ainsworth BE, Ekelund U, Freedson PS, Gary RA, et al. Guide to the assessment of physical activity: clinical and research applications: a scientific statement from the American Heart Association. Circulation. 2013;128(20):2259-79.

33. Milton K, Varela AR, Strain T, Cavill N, Foster C, Mutrie N. A review of global surveillance on the muscle strengthening and balance elements of physical activity recommendations. J Frailty Sarcopenia Falls. 2018;3(2):114-24.

34. Bull FC, Al-Ansari SS, Biddle S, Borodulin K, Buman MP, Cardon G, et al. World Health Organization 2020 guidelines on physical activity and sedentary behaviour. Br J Sports Med. 2020;54(24):1451-62.

35. Prince SA, Butler GP, Roberts KC, Lapointe P, MacKenzie AM, Colley RC, et al. Developing content for national population health surveys: an example using a newly developed sedentary behaviour module. Arch Public Health. 2019;77:53.

36. Biddle SJ, Gorely T, Marshall SJ. Is television viewing a suitable marker of sedentary behavior in young people? Ann Behav Med. 2009;38(2):147-53.

37. Ki JS, Kim H. Comparison of estimates and time series stability of Korea Community Health Survey and Korea National Health and Nutrition Examination Survey. Epidemiol Health. 2019;41:e2019012.

38. Tremblay MS, Carson V, Chaput J-P, Connor Gorber S, Dinh T, Duggan $M$, et al. Canadian 24-hour movement guidelines for children and youth: an integration of physical activity, sedentary behaviour, and sleep. Applied Physiology, Nutrition, and Metabolism. 2016;41(6 Suppl 3):S311-27.

39. Pedišić Ž, Dumuid D, Olds TS. Integrating sleep, sedentary behaviour, and physical activity research in the emerging field of time-use epidemiology: definitions, concepts, statistical methods, theoretical framework, and future directions. Kinesiology. 2017:49(2): 18 .

40. Rollo S, Antsygina O, Tremblay MS. The whole day matters: understanding 24-hour movement-guideline adherence and relationships with health indicators across the lifespan. J Sport Health Sci. 2020;9(6):493-510.

41. Troiano RP, Stamatakis E, Bull FC. How can global physical activity surveillance adapt to evolving physical activity guidelines? Needs, challenges and future directions. Br J Sports Med. 2020;54(24):1468-73.

42. Cruz MSd, Bernal RTI, Claro RM. Tendência da prática de atividade física no lazer entre adultos no Brasil (2006-2016) [Trends in leisure-time physical activity in Brazilian adults (2006-2016)]. Cad Saúde Pública. 2018;34(10):e00114817.

43. Stamatakis E, Bull FC. Putting physical activity in the "must-do" list of the global agenda. Br J Sports Med. 2020;54(24):1445-6.

Manuscript received on 13 July 2021. Revised version accepted for publication on 7 October 2021. 


\section{Medición de la actividad física y del sedentarismo en encuestas nacionales de salud en América del Sur}

RESUMEN Objetivos. Describir cómo se han medido la actividad física y el sedentarismo en las encuestas nacionales de salud en los países de América del Sur.

Métodos. Se llevó a cabo una extensa búsqueda de encuestas nacionales de salud de los doce países sudamericanos en sitios web de salud, oficinas nacionales de estadística y mediante el contacto con investigadores y responsables de formular políticas. Para escoger las encuestas se emplearon los siguientes criterios de selección: realizada en un país sudamericano; muestra representativa a nivel nacional de $\geq 18$ años; coordinada por el sector público, el sector privado o mixto público-privado; y evaluación de la actividad física o el sedentarismo. Se extrajeron datos como información general de las encuestas, detalles específicos de la evaluación de la actividad física y el sedentarismo, y otras preguntas relacionadas con la actividad física.

Resultados. En total, se incluyeron 36 encuestas, dos de las cuales se realizaron en varios países. Todas las encuestas evaluaron la actividad física; 27, el sedentarismo. La mayoría de las encuestas (23/36; 64\%) se basaron en cuestionarios internacionales anteriormente validados, de los cuales 13 (57\%) se desviaron de las herramientas de referencia al tener cambios y adaptaciones. El sedentarismo se evaluó principalmente en los mismos cuestionarios de actividad física mediante preguntas sobre el tiempo invertido delante de pantallas o el tiempo diario sentado. Ninguna encuesta aplicó medidas basadas en dispositivos para obtener datos sobre estos comportamientos.

Conclusiones. Las diferencias entre los instrumentos empleados y las modificaciones limitan la comparabilidad de los datos en todos los países. Esto pone de relieve la importancia de estandarizar la evaluación en América del Sur de las secciones dedicadas a la actividad física y al sedentarismo en las encuestas nacionales, con el objetivo general de contribuir a la creación de una estrategia estandarizada para la vigilancia de la actividad física y el sedentarismo en América del Sur.

Palabras clave Ejercicio físico; conducta sedentaria; encuestas epidemiológicas; vigilancia de la población; América del Sur.

\section{Mensuração de atividade física e comportamento sedentário em pesquisas nacionais de saúde, América do Sul}

RESUMO Objetivos. Caracterizar como a atividade física e o comportamento sedentário têm sido medidos em pesquisas nacionais de saúde em países sul-americanos.

Métodos. Foi realizada uma busca extensa de pesquisas nacionais de saúde de todos os 12 países sul-americanos em sites de saúde e órgãos nacionais de estatística, e pelo contato com pesquisadores e formuladores de políticas. Foram usados os seguintes critérios de elegibilidade para selecionar as pesquisas: conduzida em um país sul-americano; que tenha usado uma amostra nacionalmente representativa $\geq 18$ anos; coordenada pelo setor público, privado ou público-privado; e que tenha avaliado a atividade física e/ou o comportamento sedentário. Os dados extraídos eram sobre informações gerais das pesquisas, detalhes específicos sobre a avaliação da atividade física e do comportamento sedentário e questões adicionais relacionadas ao comportamento na atividade.

Resultados. Ao todo, 36 pesquisas foram incluídas, duas das quais foram conduzidas em vários países. Todas as pesquisas avaliaram a atividade física e 27 avaliaram o comportamento sedentário. A maioria das pesquisas (23/36; 64\%) baseou-se em questionários internacionais previamente validados e 13 (57\%) delas se desviaram das ferramentas de referência, introduzindo mudanças e adaptações. O comportamento sedentário foi avaliado principalmente por meio de perguntas sobre tempo de tela e/ou tempo diário sentado nos mesmos questionários sobre atividade física. Nenhuma pesquisa utilizou medições realizadas por dispositivos para gerar dados sobre esses comportamentos.

Conclusões. As diferenças entre os instrumentos usados e as modificações limitam a comparabilidade dos dados entre os países, o que destaca a importância de padronizar a avaliação na América do Sul para as seções de atividade física e comportamento sedentário em pesquisas nacionais, com o objetivo mais amplo de contribuir para o estabelecimento de uma estratégia padronizada para a vigilância da atividade física e do comportamento sedentário na América do Sul.

Palavras-chave Exercício físico; comportamento sedentário; inquéritos epidemiológicos; vigilância da população; América do Sul. 